\title{
Compliance with International Education Standards of Accounting in European Union Countries, the Case of Albania as An Official Candidate for Accession to The EU
}

\author{
Brisejda RAMAJ ZENUNI, Msc. \\ $\mathrm{PhD}$ Cand. at the Department of Accounting, University of Tirana, Faculty of Economy, Lecture in Financial and \\ Accounting Department, University of Vlora "Ismail Qemali", Faculty of Economy, Vlore, Albania \\ Mirela UJKANI MITI, PhD \\ Lecture on Accounting Departament, Faculty of Economics University of Tirana Albanian, Tirana, Albania
}

\begin{abstract}
The accountancy profession is based on standards, rests on their adoption and successful implementation, and is governed by the overarching principle of serving the public interest. These are complex sets of variables made even more difficult with sovereign interests and multiple stakeholders playing out on a global stage. The Evaluation of the status of accountancy education with its components of qualification, education and training in selected countries and Ballcan compared with the requirements of the IES. Nevertheless, the capital markets, in the aftermath of the 2008 financial crisis, are demanding a single set of high quality internationally accepted accountancy standards where transparency, comparability and reliability of financial information is paramount. The importance of adoption and implementation of IES and the use of benchmarking in identifying country accomplishments and gaps from these standards. To enhance comparability a distinction is made between the four competency sub-pillars of accountancy education: personal development, professional accountancy education, professional development, and competence requirements for auditors. Together the sub-pillars cover all IES in a comprehensive approach that strengthens the statistical analysis of the results. Country overviews contain information about the adoption and implementation of International Education Standards (IES). The discussion of the regions includes country information, regional characteristics, adoption and implementation of IES, and recognition of qualifications.
\end{abstract}

Keywords: Accountants and auditors, personal development, professional accountancy education Disciplines Accounting JEL classification: M40, M41, M48, I22, I23, I24, A23

\section{Introduction}

This paper focuses on the importance of adoption and implementation of IES and the use of benchmarking in identifying country accomplishments and gaps from these standards. To enhance comparability a distinction is made between the four competency sub-pillars of accountancy education which are: 1. personal development, 2. professional accountancy education, 3. professional development, and 4. competence requirements for auditors. Together the sub-pillars cover all IES in a comprehensive approach that strengthens the statistical analysis of the results. Using a self-assessment survey together with third party expert validation compiled with interesting results. Highlights include graphical representations of the adoption and implementation of the separate IES in diferente countries, in countries distinguished by level of development, and of countries distinguished by region. In addition to the overall analysis, graphical results for each country are presented in the separate country overviews that are attached to this paper.

\section{Literature Review}

There have been a number of studies investigating the various models of accounting education (Needles and Powers, 1990; Karreman, 2002; Phelps and Karreman, 2005; Ahern et al., 2007; Peek et al., 2007; Stainbank and Ramatho, 2007). Needles and Powers (1990) compared and analyzed the trend in 17 models for accounting education in the United States (US) and found that the development of analytical and communication skills had been neglected. Karreman (2002) 
examined the impact of globalization on accounting education in 25 countries. His study attempted to establish a connection between

The influence of differences in cultural background ('power distance' and 'uncertainty avoidance);

The present economic position (industrialized or intransition/emerging) of the countries involved;

The effect of the legal system (common law or civil law) on accounting education; and

The contribution of higher education to the qualification of accountants on the regulation of the accounting profession,

The orientation of the final examination, professional education and practical experience, education background and development of international of accounting standards was then established. His results established a link between the elements of accounting education and the country characteristics, although important differences occur (Karreman, 2002, p.139). Karreman (2002, p. 92) included European Union countires. Other studies have attempted to validate the Karreman (2002) results by using his methodology. For example, Stainbank and Ramatho (2007), benchmarked the professional accounting education programs in seven countries of the Eastern, Central and Southern African Federation of Accountants (ECSAFA) to the IES confirming the Karreman $(2002$, p. 139,141) findings that professional bodies in common law countries tend towards self-regulation as opposed to government regulation in civil law countries; that practical experience was more important in common law countries compared to civil law countries; and that developing and in transition countries tend towards a theoretical approach. In 2005, Phelps and Karreman (2005) benchmarked the countries comprising the Southern Eastern European Partnership on Accountancy Development (SEEPAD).

The above studies indicate that information on professional accountancy programs is useful as it provides new information which may further the development of accounting education, helps accounting bodies work towards international standards, assists with regional co-operation where gaps or strengths are identified, and, if weaknesses are identified and acted upon, may result in a strengthening of the professional accounting education system which could result in a better informed market. It may also help with ensuring that skills become more transportable across borders. It is important to note that countries can take individual approaches to complying with the IES and that it is not a case of "one size fits all". For example, Velayutham and Perera $(2005$, p. 32) note that there are differences between the US and United Kingdom (UK) in their approaches to accounting education.

They propose two reasons for this: (1) unlike in the US, the UK professional accounting bodies do not insist on completing an accounting major degree as pre-requisite to entry into the profession, hence the need to examine more extensively at the professional stage, and (2) there is competition among professional bodies in the UK where more than one professional body certifies members working in different areas of professional practice.

\section{Competency sub-pillars of accountancy education}

The accountancy profession is based on standards, rests on their adoption and successful implementation, and is governed by the overarching principle of serving the public interest. These are complex sets of variables made even more difficult with sovereign interests and multiple stakeholders playing out on a global stage. Nevertheless, the capital markets, in the aftermath of the 2008 financial crisis, are demanding a single set of high quality internationally accepted accountancy standards where transparency, comparability and reliability of financial information is paramount.

Naturally the stakeholders to financial reporting are now, more than ever, focused not only on adoption but also on successful implementation of internationally recognized accountancy standards. The IES ${ }^{1}$ of the International Accounting Education Standards Board (IAESB) are no exception. It is not a question of whether gaps or conversely accomplishments exist in adoption and/or implementation but rather the nature and size of the gaps and the speed of convergence. The results of this study surprisingly show a high level of achievement that far exceeds the gaps. Gaps do exist and are highlighted later in this paper.

It is important to make a distinction between adoption and implementation. Adoption refers to a formal requirement in law or regulation to include a component in the program. Implementation as discussed below addresses actual compliance with

${ }^{1}$ IFAC, International Federation of Accountants, Education, Handbook of International Education Pronouncements 2017 Edition (Current edition), www.ifac.org 
the requirement. Accelerating adoption and implementation requires measuring the gaps; formulating action plans, energizing advocacy for action and allocating resources. International accountancy standards have been promulgated and are widely known; nevertheless many problems exist including:

no enabling legislation to formally adopt these standards;

current legislation does not fully embrace the totality of the international standards;

existing legislation is confusing or contradictory;

regulations or the will for enforcement are weak;

institutions involved in accountancy lack the resources for implementation and enforcement; and,

No reliable measurement exists.

General country characteristics define the context in which accountancy education takes place. Attention is given to overall country characteristics (legal system, economic position, region), professional characteristics (professional regulation and recognition), and qualification characteristics (practice rights of accountants and auditors; international recognition of qualifications). Standards for accountancy education are formulated in the IES of the IAESB.

A distinction is made between pre-qualification requirements for accountants (IES 1-6) and post-qualification requirements for CPD (IES 7) and for auditors (IES 8). Additional standards for the qualification of auditors have been formulated by the EU (EU, 1984). The IES are published by the IAESB as standards for professional accountancy organizations that are members or associate members of International Federation of Accountants (IFAC). In the GAE 2012 global accountancy research study the IES are used as country benchmarks for adoption and implementation. This is widely accepted. A recent example is the United Nations Conference on Trade and Development UNCTAD-ISAR Accounting Development Tool $(\mathrm{ADT})^{1}$.

\section{Figure 1: Competency sub-pillars of accountancy education}

$\begin{array}{ll}\text { Competency Sub-pillars } & \\ \text { Personal Development } & \begin{array}{l}\text { University Entrance \& Exit Level (IES 1 and IES 2) } \\ \text { Professional Skills \& General Education (IES 3) } \\ \text { Professional Values, Ethics \& Attitudes (IES 4) } \\ \text { Accountancy, Finance \& Related Knowledge (IES 2) } \\ \text { Organizational \& Business Knowledge (IES 2) } \\ \text { Information Technology (IES 2) }\end{array} \\ \text { Professional Development } & \begin{array}{l}\text { Practical Experience Requirements (IES 5) } \\ \text { Assessment of Professional Capabilities \& Competence (IES 6) } \\ \text { Competence for Auditors Professionals }\end{array} \\ & \begin{array}{l}\text { Advanced Professional Knowledge (IES 8) } \\ \text { Advanced Professional Skills, Values, Ethics \& Attitudes (IES 8) } \\ \text { Advanced Practical Experience, Assessment \& CPD (IES 8) }\end{array} \\ & \end{array}$

\section{Source: GAE 2012, Dynamics of Global Accountancy Education}

Competency pillars for accountants and auditors can help in the analysis of their qualifications. A distinction is made between personal development, professional accountancy education, professional development, and competency requirements for auditors.

\footnotetext{
1 UNCTAD, United Nations Conference on Trade and Development, ISAR, www.unctad.org/isar
} 
Sub-pillar 1, personal development, combines elements that in many countries are achieved through university education. Sub-pillar 2, professional accountancy education, emphasises competences in accounting, finance \& related knowledge; in organizational \& business knowledge; and in information technology. Normally courses are provided by universities and/or professional accountancy organizations.

Sub-pillar 3, professional development, combines practical experience, assessment of professional competence, and CPD. Normally the accountancy profession is leading in these areas.

Sub-pillar 4, competency for audit professionals, includes higher level requirements for licensed accountants and auditors.

According to the IAESB the IES "prescribe standards of generally accepted 'good practice' in the education and development of professional accountants. IES are intended to advance the profession of accountancy by establishing benchmarks for the minimum learning requirements of qualified accountants, including education, practical experience and continuing professional development". The overview in this paragraph is based on the Handbook of International Education Pronouncements (IFAC, 2010a). The goal of accounting education is to produce competent professional accountants capable of making a positive contribution over their lifetimes to the profession and society in which they work. The IAESB recognizes that IES may be complied with in a variety of different ways.

The entry requirement to begin a program of professional accounting education leading to membership of an IFAC member body should be at least equivalent to that for admission into a recognized university degree program or its equivalent (IES 1). Professional accounting study should be long and intensive enough to permit candidates to gain the professional knowledge required for professional accountants (IES 2).

As part of their pre-qualification education, all professional accountants are expected to participate in at least one of the roles of manager, designer or evaluator of information systems, or, a cluster of these roles (IES 2). Technical and functional skills consist of general skills as well as skills specific to accountancy. Personal skills relate to the attitudes and behavior of professional accountants. Interpersonal and communication skills enable a professional accountant to work with others, receive and transmit information, form reasoned judgments and make decisions effectively. Organizational and business management skills have become increasingly important to professional accountants (IES 3).

The coverage of values, ethics and attitudes should lead to a commitment to the public interest; continual improvement and lifelong learning; reliability and responsibility; and laws and regulation (IES 4). The period of practical experience should be long enough and intensive enough to permit candidates to demonstrate they have gained the professional knowledge, professional skills, and professional values, ethics and attitudes required for performing their work with professional competence (IES 5).

The professional capabilities and competence of candidates should be formally assessed before the qualification of professional accountant is awarded. The assessments need to be appropriate for the professional knowledge, professional skills and professional values, ethics and attitudes being evaluated. The final assessment of capabilities and competence is normally in addition to purely academic qualifications and is beyond undergraduate degree level (IES 6).

IFAC member bodies should implement a CPD requirement as an integral component of a professional accountant's continued membership. According to the CPD requirement all professional accountants have to develop and maintain competence relevant and appropriate to their work and professional responsibilities (IES 7). Advanced requirements for audit professionals are necessary not only because of the specialist knowledge and skills required for competent performance in this area, but also because of the reliance the public and other third parties place on the audit of historical financial information.

Audit professionals are required to qualify as a professional accountant, hold an undergraduate degree or comparable, and satisfy advanced program requirements, professional skills, values, ethics and attitudes, as well as practical experience before qualification, and CPD for auditors after qualification (IES 8).

An overview of the IES is presented in figure 2 . 


\section{Figure 2: International Education Standards ${ }^{1}$}

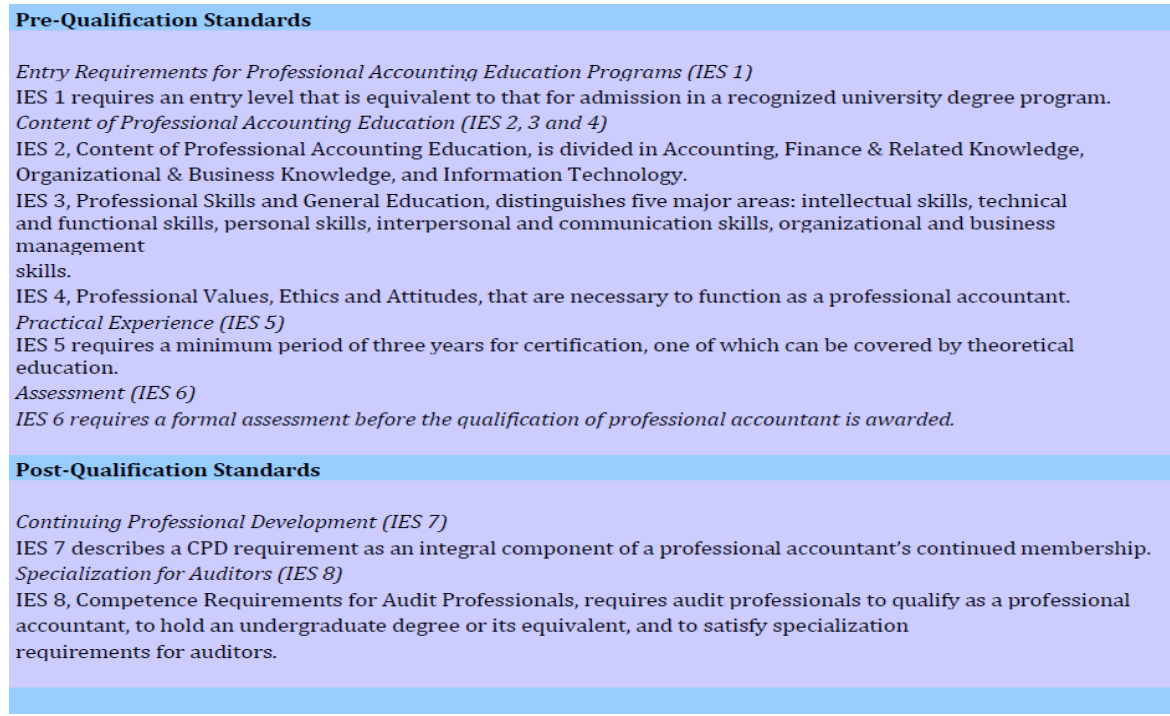

\section{Source: Global Accountancy Education Recognition Study 2012 (NASBA 2013)²}

SMO 2 is comprehensive which naturally covers the multidisciplinary requirements of accountancy education. Over 100 questions were presented in the questionnaire which resulted in data that is in depth purposely to assist in removing, as much as possible, ambiguities from the respondents view point. But more importantly, questions cover both adoption and implementation. Table1:Sub-pillar Outline

\begin{tabular}{|c|c|c|}
\hline Sub-pillars & Milestones & Questionnaire \\
\hline $\begin{array}{l}\text { Sub-pillar } 1 \\
\text { Personal Development }\end{array}$ & $\begin{array}{l}\text { 1.1 Academic Entry \& Exit Level } \\
\text { 1.2 Intellectual \& Technical Skills } \\
\text { 1.3 Values, Ethics \& Attitudes }\end{array}$ & $\begin{array}{l}\text { 2.1 University Entry Level (IES 1) } \\
\text { 2.2.1 Academic Level (IES 2) } \\
\text { 2.3 Professional Skills (IES 3) } \\
\text { 2.0.2 IFAC Code of Ethics } \\
\text { 2.4 Professional Values, Ethics \& } \\
\text { Attitudes (IES 4) }\end{array}$ \\
\hline $\begin{array}{l}\text { Sub-pillar } 2 \\
\text { Professional Accountancy } \\
\text { Education }\end{array}$ & $\begin{array}{l}2.1 \text { Accounting, Finance \& } \\
\text { related Knowledge } \\
2.2 \text { Organizational \& Business } \\
\text { Knowledge } \\
2.3 \text { Information Technology }\end{array}$ & $\begin{array}{l}\text { 2.2.2 Accounting, Finance \& } \\
\text { related Knowledge (IES } 2 \text { ) } \\
2.2 .3 \text { Organizational \& Business } \\
\text { Knowledge (IES } 2 \text { ) } \\
2.2 .4 \text { Information Technology } \\
\text { (IES 2) }\end{array}$ \\
\hline $\begin{array}{l}\text { Sub-pillar } 3 \\
\text { Professional Development }\end{array}$ & $\begin{array}{l}\text { 3.1 Practical Experience } \\
\text { 3.2 Assessment } \\
\text { 3.3 Continuing Professional } \\
\text { Development }\end{array}$ & $\begin{array}{l}\text { 2.5. Practical Experience (IES 5) } \\
2.6 \text { Assessment of Professional } \\
\text { Capabilities and Competence } \\
\text { (IES 6) } \\
2.7 \text { Continuing Professional } \\
\text { Development (IES } 7 \text { ) }\end{array}$ \\
\hline $\begin{array}{l}\text { Sub-pillar } 4 \\
\text { Competence for Audit } \\
\text { Professionals }\end{array}$ & $\begin{array}{l}\text { 4.1 Advanced Audit Program } \\
4.2 \text { Advanced Audit Skills \& } \\
\text { Ethics } \\
4.3 \text { Advanced Audit Professional } \\
\text { Requirements }\end{array}$ & $\begin{array}{l}\text { 2.8.1 Advanced Audit Program } \\
\text { (IES 8) } \\
\text { 2.8.2 Advanced Audit Skills (IES } \\
\text { 8) } \\
\text { 2.8.4 Practical Experience in an } \\
\text { Audit Environment (IES } 8 \text { ) } \\
\text { 2.8.5 Advanced Assessment for } \\
\text { Audit Professionals (IES } 8 \text { ) } \\
\text { 2.8.6 CPD Requirements for } \\
\text { Audit Professionals (IES } 8 \text { ) }\end{array}$ \\
\hline
\end{tabular}

1 IFAC, International Federation of Accountants, Education, Handbook of International Education Pronouncements 2010 Edition (Current edition), www.ifac.org

${ }^{2}$ Global Accountancy Education Recognition Study 2012 (NASBA 2013)Professor Dr Gert H. KarremanProfessor Belverd E. Needles Ph.D., CPA, CMA, page 20 


\section{Source: Global Accountancy Education Recognition Study 2012 (NASBA 2013)}

The time table of IES, In 2009, the International Accounting Education Standards Board (IAESB) agreed that all eight standards should be revised with the aim of improving clarity, ensuring consistency with concepts of the Framework for International Education Standards for Professional Accountants (the Framework), clarifying issues resulting from changes in the environment of accounting education and the experience gained from implementation of the IES by IFAC member bodies. Like IFRS, the IAESB is adopting a principles-based approach to develop the IES using the educational concepts and principles of the Framework As of November 2012 the IAESB has approved the following IES: IES 1, Entry Requirements to Professional Accounting Education Programs (Revised) (IES 1 prescribes the principles to be used when setting and communicating educational requirements for entry to professional accounting education programs.) This IES is effective from 1 July 2014. IES 6, Initial Professional Development - Assessment of Professional Competence (Revised) (IES 6 prescribes the requirements for the assessment of professional competence of aspiring professional accountants that need to be achieved by the end of Initial Professional Development.) This IES is effective from 1 July 2015. IES 7, Continuing Professional Development (Redrafted) (IES 7 prescribes the continuing professional development (CPD) required for professional accountants to develop and maintain the professional competence necessary to provide high quality services to clients, employers, and other stakeholders, and thereby to strengthen public trust in the profession.) This IES is effective from 1 January 2014.

\section{Albania as an official candidate for accession to the EU}

Since 1947, together with the establishing of the command economy and nationalizing the property rights on all kinds of property, the need to establish an accounting system, to reflect and report on relationships of the individual entities to the communist government, became evident. The first accounting system was copied by the former Soviet Union and then translated in accordance with the needs and mentality of Albanian accountants. There was also an influence from the Italian school, because most of the accountants and academics involved in accountancy field, especially during the first years of communist regime, were coming from that school. Based on the laid down objectives of the command economy, the primary goal of accounting was "to follow up step by step" the accomplishment of planned numbers. So, the basic task of accounting information was to produce periodically relevant actual data for each of the planned indices and serve for analyzing of the economic performance. Another task of accounting was to serve to the safeguarding and use of enterprises' assets. The former accountancy system constituted by a simplified Chart of Accounts and the application of the rule of the Civil Code, The Chart of Accounts was used for the planning process and reconciling the National Public Accounts. The main aim of financial reporting was to present information on the financial position of the enterprises during financial periods for their limited range of users. Amongst the users of the financial statements were the Government agencies direct responsible for the respective industries, Bank of Albania, on which was laid the responsibility of the payments system and the settlement agency among different entities. User of the financial statements was also the National Planning Commission (a kind of Ministry of Planning Economy).

In Albania there was not any basis to design or to invent our own original system. The only way in our post-communist environment was the selection, adaptation and implementation of a model that would be in line with EU Directives and EU practices. Taking into the consideration our country integration goals, and the former legal and professional traditions, any model selected has to be one that could be implemented easily in practice.

At that time, while working to install a new accountancy profession and new accounting standards, the experts involved, along side the model they chosen for implementation, also they have taken into account the international benchmarks reflected in the IASs and ISAs, so the new legislation included most of the principles and policies arising by these benchmarks. Requirements arising from other related laws and regulations, law "On commercial companies" provided to some extent for the selection of EU model of continental accounting system. Regulation for commercial companies requires the preparation and presentation of financial statements in a format and methodology that reflect the true and fair view of the financial position of the entities and their cash flows during the accounting period.

\section{Development and Enhancement of Accountancy Professions}

Part of the accounting reform was the development of the independent accountancy professions that will be able to provide relevant services to the business entities independently, practices that were not known until now. Even in this area, there

${ }_{1}^{1}$ Global Accountancy Education Recognition Study 2012 (NASBA 2013)Professor Dr Gert H. KarremanProfessor Belverd E. Needles Ph.D., CPA, CMA, page 20 
was no need for any invention. EU models already exist, so the main focus of the work would be on adopting a model relevant to our conditions and to our accounting system chosen. Here below is described briefly the development and actual situation of the two independent accounting professions (certified accountant and chartered auditor).

Albania like other southeastern European countries must increase both domestic and foreign investments in order to achieve the expected levels of economy growth. However, at present foreign and domestic investors often presume that the financial reporting provides limited information about the real financial conditions of the enterprise. This is especially true for small and medium sized enterprises that need to establish confidence of potential lenders and investors. Although, during the last decade has been made a considerable progress, major reform of accounting practice still need to take place, because while is not evidenced a sufficiently high level of commitment on the fundamental accounting principles applicable in a market economy, a significant priority were given to auditing, despite the fact that there was very little scope for a real auditing due to lack of proper accounts.

The standard setters are the International Federation of Accountants (IFAC), the International Accounting Education Standards Board (IAESB), the European Union (EU) ${ }^{1}$ and the International Auditing and Assurance Standards Board (IAASB).

IFAC and IAESB: The IFAC Statements of Membership Obligations (SMOs) summarize the requirements for IFAC member bodies. SMO 2 requires compliance with IAESB International Education Standards (IES) but this is only mandatory if the IFAC member body is directly responsible. According to IFAC "globally accepted standards should minimize differences between countries and jurisdictions, thus reducing international differences in the requirements to qualify and work as a professional accountant". IFAC does not address responsibility for qualifications and accepts differences between countries. The IES are promoted as benchmarks; recognition of qualifications between countries is not considered as a specific subject.

European Union: Qualification requirements for auditors are included in the EU 8th Directive; EU Member States must include the requirements in national law. The requirements cover university entrance level, program subjects relevant for auditors, practical experience in an auditing environment, assessment at university final examination level, and CPD. The EU only regulates auditors in view of their public function; there is no regulation for accountants in the 8th Directive. Each Member State has to establish procedures for the approval of statutory auditors from other Member States. At present an aptitude test is required that is limited to national law and professional rules relevant for auditors. In future it may also be possible for candidates to choose an adaptation period.

IFAC and IAASB: The IAASB is responsible for the ISA. According to ISA 600 a group engagement team has, among others, to obtain an understanding of the component auditor's professional competence. ISA 600 does not refer to applicable international standards on the qualification, education and training of local experts. It can be argued that this creates uncertainty for the selection of benchmarks that can ensure that ISA 600 requirements are met.

There are two major differences between IFAC and EU regulation. The IFAC IES cover competence requirements for accountants and auditors; although the IES are increasingly used as country benchmarks, they are only mandatory when a professional accountancy organization is responsible. The EU 8th Directive (EU, 1984) is mandatory for auditors, the position of accountants is not considered; the requirements are implemented in national law for each country in the EU. For consideration outside the EU it is necessary to consider that EU auditor qualifications are considered to be equivalent. The requirements of the 8th Directive are so general that actually major differences between EU countries still exist. This has to be taken into account when recognition of auditor qualifications between EU countries and countries outside the EU is considered. The review of the component auditor's competence required by ISA 600 is not based on consideration of any international standard.

Our country, as many reforms undertaken by countries in transition, has started the reforms in accounting field in cooperation with the World Bank, which was first finalised with the creation of the full National Accounting Standards set, which was first implemented in Albania in 2008. These reforms didn't stop but continued to fit EU requirements and directives by improving NAS ${ }^{2}$ and suitability with IFRS ${ }^{3}$ for $\mathrm{SME}^{4}$ which started to be implemented immediately.

\footnotetext{
${ }^{1}$ EU, European Union, europa.eu/Information_en.htm

2 National Accounting Standards in Albania

3 International Financial Reporting Standards

${ }^{4}$ Small and Medium Enterpise
} 
Certainly that the cooperation of Albanian regulatory institutions is in it's continuity with the World Bank project where actually the cooperation field is accounting education as well.

\section{Conclusion}

It is of interest to consider how some major players approach the recognition of qualifications and whether their conclusions are based on applicable international standards for professional qualifications of accountants and auditors. In the analysis three standard setters are considered and three professional conglomerates and one global organization.

Albania like other southeastern European countries must increase both domestic and foreign investments in order to achieve the expected levels of economy growth. However, at present foreign and domestic investors often presume that the financial reporting provides limited information about the real financial conditions of the enterprise.

During the last decade has been made a considerable progress, major reform of accounting practice still need to take place, because while is not evidenced a sufficiently high level of commitment on the fundamental accounting principles applicable in a market economy, a significant priority were given to auditing, despite the fact that there was very little scope for a real auditing due to lack of proper accounts.

There are two major differences between IFAC and EU regulation. The IFAC IES cover competence requirements for accountants and auditors; although the IES are increasingly used as country benchmarks, they are only mandatory when a professional accountancy organization is responsible. The EU 8th Directive (EU, 1984) is mandatory for auditors, the position of accountants is not considered; the requirements are implemented in national law for each country in the EU. Albania needs more work with the implementation of International Education Standards.

For consideration outside the EU it is necessary to consider that EU auditor qualifications are considered to be equivalent. The requirements of the 8th Directive are so general that actually major differences between EU countries still exist. This has to be taken into account when recognition of auditor qualifications between EU countries and countries outside the EU is considered. The review of the component auditor's competence required by ISA 600 is not based on consideration of any international standard.

Our country, as many reforms undertaken by countries in transition, has started the reforms in accounting field in cooperation with the World Bank, which was first finalised with the creation of the full National Accounting Standards set, which was first implemented in Albania in 2008.

\section{Reference}

[1] EU, European Union, europa.eu/Information_en.htm FEE,

[2] Federation of European Accountants, www.fee.be FIDEF,

[3] International Federation of Francophone Accountants, www.fidef.org

[4] EU, European Union, europa.eu/Information_en.htm

[5] FEE, Federation of European Accountants, www.fee.be FIDEF, International Federation of Francophone Accountants, www.fidef.org

[6] WTO, World Trade Organization, www.wto.org

[7] WB, World Bank, www.worldbank.org

[8] IFAC, International Federation of Accountants, Education, Handbook of International Education Pronouncements 2010 Edition (Current edition), www.ifac.org

[9] UNCTAD, United Nations Conference on Trade and Development, ISAR, www.unctad.org/isar

[10] Global Accountancy Education Recognition Study 2012 (NASBA 2013)Professor Dr Gert H. KarremanProfessor Belverd E. Needles Ph.D., CPA, CMA, page 20 